\section{The Danger of Forgetting the Social Benefits of Higher Education}

\section{Christine Musselin}

Christine Musselin is vice president for research at SciencesPo, Paris, France. E-mail: Christine.musselin@sciencespo.fr.

One of the main assumptions behind the discourse on the increasing need for more higher education-a discourse that proved to be very effective when one looks at the exponential increase in student numbers during the 2oth century-was that higher education will have strong social benefits. Indeed, some studies show that educated people get higher wages, have better living conditions and better health, and are more open-minded.

A key challenge for higher education in the coming decades will be to maintain these beliefs and to convince society that education and training do more than produce human capital-but also have a larger social function and purpose. Knowledge is not only important for its economic value but also for society.

Recently, the social contribution of higher education has been ignored or even distained by policymakers, the governments of developed countries, as they stressed the need for more knowledge and innovation in order to promote economic progress. Training more highly qualified workers, able to understand and produce knowledge, was presented as a challenge for countries involved in the global knowledge economy. What was learned at universities was considered to be less important than the job one could obtain at the end of their studies.

My point here is not to say that preparing students for the job market is not an important mission for universities, or that transforming research into economic relevance should not be assumed by higher education. Yet, this should not mean the abandonment of other missions and activities, the development of purely instrumental training programs, the end of "blue sky" research, or the end of disciplines that may have no direct economic impact.

This challenge is all the more important because obscurantism, ignorance, intolerance, and fanaticism are unfortunately expanding. Recent events in Europe, terrible conflicts in some African and Middle-East countries, and the civil war in Ukraine all prove that higher education institutions still have to promote humanistic values, prepare for citizenship, and to be socially responsible. These missions have never been sufficient to prevent from all misconducts and abuses-some well-trained individuals have in some cases proved to be as fanatic as noneducated ones-but they have nevertheless been largely effective. They, therefore, absolutely must be maintained and even reinforced. This might be a difficult line to hold at a time when higher education policies first of all promote the economic and instrumental roles of universities. However, it is a battle to lead and win in the coming decades, if universities are to remain a place where knowledge and humanistic values are protected and diffused.

\section{The Misuses of the University}

\section{Patti McGill Peterson}

Patti McGill Peterson is Presidential Advisor for global initiatives at the American Council of Education and former executive director of the Council for the International Exchange of Scholars-The Fulbright Program.E-mail: ppeterson@acenet.edu.

We live in an age where understanding your core mission and being true to it are fundamental concepts for healthy organizations. My concern for the future of higher education is the number of stakeholders, who place upon it an ever-expanding list of competing demands and their impact on its core mission.

When Cardinal Newman wrote about universities in the I850s, he wanted to define not only their purpose for students but also their purpose in society. Central to Newman's conception was the student and the environment for teaching and learning. It was connected to society but not driven or heavily shaped by it.

Fast forward to Clark Kerr about ioo years later-the uses of the university trump the idea of the university. His "multiversity" is a mega purpose institution-a place of competing visions and, according to Kerr, is so many things to so many other people that it must be at war with itself.

Juxtaposing Newman and Kerr is not merely an act of nostalgia. It is a signal that demands on universities, and higher education in general have grown exponentially. Higher education has been placed increasingly in the position of providing the antidote for whatever issues governments, business and industry, major donors, and other stakeholders define as needing solution.

In this scenario, it is very difficult to be true to a core educational mission and to plan strategically to enhance it over time. Institutions are like Napoleon on the Russian front, with their line of advance too wide and their supply 
lines too short.

All higher education institutions, not just those tertiary institutions with vocational missions, are increasingly held accountable for matching their education offerings with workforce needs and the employability of their graduates. This has led to the steady "vocationalization" of higher education at the undergraduate level.

The dangers of designing higher education curricula for immediate usefulness are real. Gearing degrees to the contemporary workplace and training students for specific jobs can potentially pave the way to chronic unemployment. The forces of globalization and new discoveries can shutter factories, bypass entire industries, and throw graduates who are narrowly educated on the slag pile of human obsolescence.

While we need not return to the Studium Generale to be true to higher education's core mission, it is time to consider how to balance relevance with timelessness and shortterm usefulness with long-term competency. As we look to the future, we need to reckon with what "useful" means in considering higher education's obligations to its students and society. If the core mission is to educate students well for a lifetime, its usefulness will include an intellect developed for a personally rewarding life, the wherewithal for informed citizenship, and the ability to move productively between multiple jobs and careers.

Great universities and well-developed higher education systems will legitimately be asked to respond to societal needs. The challenge will be in managing those demands without losing the very thing that has made them great.

\section{Chinese Higher Education: Future Challenges}

\section{Gerald A. Postiglione}

Gerard A. Postiglione is chair professor and associate dean, Faculty of Education, University of Hong Kong. E-mail: gerry.hku@gmail.com.

For 2020, the key question is: Will China be a major or fractional power in international higher education with a unique and exportable university model? Several contemporary book titles indicate that it is a question worth asking: When China Rules the World; The Post-American World and the Rise of the Rest; Will China dominate the 21st Century?

As China inches toward becoming the world's largest economy, there are indications of an economic slowdown and concern about how this will affect higher education. China already has the most students in higher education, more scientific publications, and a larger budget for research and development than any country in the world, except the United States. Several flagship universities have gained a world-class ranking, though the system as a whole does poorly on quality indicators. It bodes well for the future of Chinese higher education, which prospective students in its largest city outperform counterparts in mathematics and science in a 6o-country Organization for Economic Cooperation and Development assessment.

While the debate continues in China about how to build a unique university model to compliment the Beijing Consensus, efforts to shape universities with indigenous ideas are stymied by the race for global rankings. Meanwhile, universities struggle with uninspiring teaching that is reflected in media outlets that report students are sleeping through lectures. Recent research shows many teachers liven up their classes by criticizing government and the Communist Party, leading to a call for more teaching of Marxism. China's leaders also understand that its universities are not only instruments of knowledge creation and dissemination, but also instruments of international competition. Initiatives are under way to foster soft skills in the science, technology, engineering, and mathematics fields to drive industrial innovation and China's economic globalization. Despite such efforts, the transition to mass higher education is plagued by a burgeoning of unemployed graduates.

The global influence of China's universities in 2025 will hinge on how it handles a precarious balance between domestic demands and aspirations to go global. The domestic demands include those by employers for knowledge and skills to upgrade production, by urban, middle-class households for status culture that distinguished their children, and by the rural poor, migrants, and minorities for equitable access and jobs. These demands remain subsidiary to the state's demand for national prosperity, power and strength, stability and unity. The state orchestrates the aspirations of universities to going global by demanding that internationalization does not sacrifice educational sovereignty, even while the state must eventually cede more autonomy to universities.

By 2020 , more Chinese citizens will have a college education than the entire workforce of the United States. While sending more students to the United States than any other country, China itself is fast becoming one of the most popular international destinations for overseas study. Harvard's Vogel may be right that the result of China's opening and reform for higher education has been an intellectual vitality as broad and deep as the Western Renaissance. But the extent to which China will have a unique and exportable model that powers international higher education in 2020 remains a key question. 